\title{
PERKEMBANGAN KEBIJAKAN NILAI TUKAR RUPIAH DAN PERTUMBUHAN EKONOMI INDONESIA
}

\author{
Fitriyani $^{1 *}$, Diana Sapha ${ }^{2}$, Cut Zakia Rizki ${ }^{3}$, Nur Aidar $^{4}$, Ferayanti $^{5}$, \\ Muhammad Ilhamsyah Siregar ${ }^{6}$, Amsal Irmalis ${ }^{7}$ \\ 1,2,3,4,5,6 Fakultas Ekonomi dan Bisnis, Universitas Syiah Kuala \\ ${ }^{7}$ Fakultas Ekonomi Universitas Teuku Umar \\ *Corresponding Author: fitriyani@unsyiah.ac.id
}

\begin{abstract}
Abstrak
Penelitian ini bertujuan untuk menjelaskan deskriptif perkembangan kebijakan system kurs, inflasi, dan GDP di Indonesia. Model analisis deskriptif digunakan dengan membagi 3 periode penelitian, yaitu penerapan system nilai tukar tetap pada Tahun 1975-1978, mengambang terkendali pada tahun 19781997, dan periode mengambang bebas pada tahun 1997-2018. Data yang digunakan merupakan data tahunan yang bersumber dari world bank, federal reserve economic data, dan Bank Indonesia. Hasil penelitian menunjukkan bahwa perkembangan system nilai tukar di Indonesia mengalami fluktuasi sepanjang tahun. Hal ini berdampak pada tingkat pertumbuhan ekonomi dan inflasi yang juga tidak stabil. Oleh karena itu, upaya menstabilkan nilai tukar rupiah perlu dilakukan oleh Bank Indonesia. Selanjutnya, untuk further study, perlu menganalisis lebih lanjut bagaimana 3 periode system nilai tukar bekerja secara efektif dalam mentransmisikan kebijakan moneter melalui jalur nilai tukar terhadap variabel makro.
\end{abstract}

Kata Kunci: Nilai tukar, pertumbuhan ekonomi, inflasi

\begin{abstract}
This study aims to analyze the development of exchange rate system, inflation and economic growth policies in Indonesia. The model used is a descriptive analysis model by dividing 3 exchange rate regimes from 1978 to 2018. The data used is annual data sourced from the world bank, the federal reserve economic data, and Bank Indonesia. The results showed that the exchange rate system in Indonesia is fluctuated throughout the year. This has an impact on economic growth rate and inflation which is also unstable. Therefore, Bank Indonesia must stabilize the rupiah exchange rate. For further research, it is also advisable to further analyze how the 3 periods of the exchange rate regimes work effectively in transmitting monetary policy through the exchange rate channel to macro variables.
\end{abstract}

Key Words: Exchange rate, growth rate, inflation 


\section{Jurnal Bisnis dan Kajian Strategi Manajemen}

Volume 3 Nomor 1, 2019

ISSN : 2614-2147

\section{Latar Belakang}

Kebijakan moneter yang diterapkan oleh Bank Sentral memiliki peran yang cukup signifikan dalam perekonomian. Keadaan baik atau buruknya perekonomian suatu negara tercermin dari kebijakan moneter yang diterapkan oleh pelaku perekonomian. Seperti yang kita ketahui, Bank Indonesia sebagai salah satu pelaku perekonomian memegang peranan penting dalam kebijakan moneter. Hal ini terlihat pada kebijakan moneter yang diterapkan oleh Bank Indonesia, seperti pengendalian harga, money supply, dan sebagainya. Kebijakankebijakan tersebut secara langsung maupun tidak langsung mempengaruhi aktivitas perekonomian.

Warjiyo (2004:2) mengatakan bahwa kebijakan moneter mempengaruhi perputaran uang dalam perekonomian. Kebijakan moneter yang dilakukan Bank Indonesai melalui mempengaruhi perkembangan variabel ekonomi dan keuangan lainnya seperti nilai tukar, jumlah uang beredar dan inflasi. Kebijakan moneter yang diterapkan oleh Bank Sentral tersebut juga dapat mempengaruhi output riil di samping pengaruhnya terhadap harga. Selain itu juga melalui mekanisme transmisi kebijakan moneter dapat dianalisis pula bagaimana dan melalui mekanisme seperti apa pengaruh kebijakan moneter tersebut terjadi (Blinder dan Bernanke, 1992).

Peran Bank Indonesia "bertujuan untuk mencapai dan memelihara kestabilan nilai rupiah, yaitu kestabilan nilai tukar rupiah dan kestabilan harga (inflasi)". Oleh karena itu, nilai tukar rupiah dan inflasi berperan penting dalam meningkatkan serta menjaga sustainable economics development.

Pengefektifan kebijakan moneter melalui jumlah uang beredar telah lama dijadikan sebagai dasar kebijakan moneter di Indonesia. Namun dalam perkembangan perekonomian, penggunaannya tidak lagi relevan. Globalisasi menyebabkan sektor keuangan dan perbankan berkembang pesat. Definisi uang beredar semakin luas karena banyaknya inovasi-inovasi produk perbankan. Oleh karena itu, perlu kebijakan mekanisme transmisi yang sesuai untuk kondisi moneter Indonesia masa kini, salah satunya melalui jalur nilai tukar (Warjiyo, 2004:32).

Kondisi nilai tukar global sangat berpengaruh terhadap perekonomian Indonesia karena perekonomian Indonesia merupakan ekonomi terbuka kecil. Artinya, perekonomian Indonesia tidak mampu mempengaruhi perkonomian global, justru sebaliknya perekonomian Indonesia dipengaruhi oleh perekonomian global. Perkembangan dan fluktuasi nilai tukar ini juga berpengaruh terhadap harga barang barang impor maupun ekspor Indonesia sehingga akan berpengaruh pula terhadap permintaan akan barang impor maupun ekspor. Depresiasi rupiah menyebabkan harga barang impor di Indonesia menjadi lebih mahal dan ekspor Indonesia di luar negeri murah dan mudah bersaing. Penurunan pada ekspor ini berdampak pula pada tingkat pertumbuhan ekonomi yang ikut menurun dan penurunan pula pada kegiatan perekonomian.

Negara yang mengalami kemunduran dalam perekonomian atau tengah dilanda krisis terlihat pada melemahnya nilai tukar negara tersebut terhadap negara lain. Negara Indonesia pernah mengalami kondisi serupa, pada Tahun 1997 nilai tukar rupiah Indonesia terdeprisiasi terhadap US Dollar. Kondisi ini menyebabkan inflasi di Indonesai mengalami peningkatan yang cukup signifikan 


\section{Jurnal Bisnis dan Kajian Strategi Manajemen}

Volume 3 Nomor 1, 2019

ISSN : 2614-2147

dan berujung pada terjadinya krisis moneter. Kondisi ini tentu menunjukkan seberapa berpengaruhnya nilai tukar terhadap perekonomian. Sejak tahun 1964, Indonesia sendiri telah mengalami 3 kali sistem nilai tukar, yaitu system fixed exchange rate (nilai tukar tetap), free floating exchanged rate (sistem nilai tukar mengambang bebas), dan managed floating exchange rate (sistem nilai tukar mengambang terkendali). Pendekatan mengenai kebijakan nilai tukar yang tepat bagi Indonesia terus bergulir setiap terjadi tekanan yang tinggi pada rupiah dan juga ketika rupiah mengalami penguatan. Untuk melihat perkembangan kurs dapat dilihat pada Tabel 1 .

Tabel 1. Penerapan Kebijakan Sistem Nilai Tukar di Indonesia

\begin{tabular}{|l|l|}
\hline \multicolumn{1}{|c|}{ Tahun } & \multicolumn{1}{c|}{ Sistem Nilai Tukar } \\
\hline $1964-1978$ & Sistem nilai tukar tetap \\
\hline $1978-1997$ & Sistem nilai tukar mengambang terkendali \\
\hline 1997-sekarang & Sistem nilai tukar mengambang bebas \\
\hline
\end{tabular}

Sumber: Bank Indonesia, Kebijakan Moneter (2012).

Menurut Sulasmiyati (2008) berdasarkan Undang-Undang Nomor 32 tahun 1964, Indonesia menerapkan sistem nilai tukar tetap dengan nilai tukar resmi Rp250/USD. Selama pemberlakuan sistem ini, Bank Indonesia melakukan intervensi aktif di pasar valuta asing dengan mengontrol cadangan devisa negara. Sistem nilai tukar mengambang terkendali di Indonesia ditetapkan bersamaan dengan kebijakan devaluasi rupiah. Kurs tetap dipertahankan pada tingkat Rp415/USD sejak 1971 sampai dengan pertengahan November 1998. Hal ini berpengaruh terhadap tingkat inflasi dalam negeri yang lebih tinggi dibandingkan inflasi di negara mitra dagang utama sehingga mengakibatkan melemahnya daya saing produksi dalam negeri.

Oleh karena itu, untuk memperkuat daya saing barang-barang produksi dalam negeri, pemerintah melakukan devaluasi rupiah terhadap dollar sebesar 34 persen dan sejak itu Indonesia menganut kebijakan nilai tukar mengambang terkendali. Akibat devaluasi dan tingkat inflasi yang dikendalikan, jumlah ekspor bukan migas meningkat. Indonesia mengalami surplus neraca pembayaran. Namun, nilai tukar rupiah terus mengalami depresiasi yang semakin menyebabkan pengurangan pada cadangan devisa. Depresiasi nilai tukar ini tentunya tidak berdampak baik bagi perekonomian Indonesia walaupun di sisi lain menguntungkan eksportir karena harga barang-barang khususnya barang-barang impor menjadi lebih mahal.

Pada tahun 1997-sekarang Indonesia menerapkan kurs bebas. Kondisi krisis menyebabkan peningkatan pembelian valas. Untuk mengantisipasi krisis, pemerintah ketika itu melebarkan rentang intervensi (intervention band) pada Juli 1997 (Sulasmiyati, 2008). Hal ini ternyata tidak mampu mengatasi fluktuasi nilai tukar rupiah, sebaliknya fluktuasi rupiah justru semakin tidak terkendali. Oleh karena itu, pada tanggal 1 Agustus 1997 pemerintah melepas batas intervensi. Akibatnya, kurs melonjak tinggi di mana pada tahun 1998, nilai kurs Indonesia terhadap dollar Amerika mencapai Rp8.025/USD. Fluktuasi kurs ini sangat berpengaruh terhadap GDP dan inflasi di mana tingkat kurs yang melonjak tajam menyebabkan pertumbuhan ekonomi Indonesia mencapai minus dan inflasi menjadi sangat tinggi.

Penelitian mengenai mekanisme transmisi kebijakan moneter terhadap output 


\section{Jurnal Bisnis dan Kajian Strategi Manajemen}

Volume 3 Nomor 1, 2019

ISSN : 2614-2147

riil dan inflasi dilakukan oleh Hung dan Pfau (2008) di Vietnam dengan menggunakan model VAR (Vector Autoregression). Politik diskonto, operasi pasar terbuka, dan cadangan wajib minimum digunakan sebagai instrumen kebijakan moneter. Pengujian dilakukan melalui analisis VAR dengan variabel inflasi, suku bunga riil, nilai tukar riil, jumlah uang beredar, output riil, dan kredit untuk melihat keefektifan kebijakan moneter dalam mempengaruhi output riil dan tingkat harga.

Hasil penelitian menunjukkan bahwa mekanisme transmisi moneter melalui jalur nilai tukar dan jalur kredit lebih efektif dibandingkan mekanisme transmisi moneter melalui jalur suku bunga. Hal ini disebabkan, suku bunga tidak mempengaruhi permintaan dan penawaran uang di pasar keuangan. Melalui jalur nilai tukar, nilai tukar riil dan penawaran uang merupakan variabel utama dalam mempengaruhi output. Sedangkan melalui jalur kredit mempengaruhi output melalui peningkatan penawaran uang yang akan meningkatkan total kredit sehingga mendorong permintaan agregat dan output.

Cevik dan Teksoz (2012) menganalisis keefektifan jalur mekanisme transmisi moneter di negara Gulf Cooperation Council (GCC) menggunakan model Structural Vector Autoregression (SVAR). Hasil penelitian menunjukkan jalur suku bunga dan jalur kredit bekerja secara efektif mempengaruhi output dan harga. Sedangkan jalur nilai tukar belum berperan dalam mentransmisikan kebijakan moneter di GCC. Hal ini disebabkan negara GCC menerapkan sistem nilai tukar tetap.

Sementara itu, Rosoiu dan Rosoiu (2013) menganalisis tentang mekanisme transmisi moneter di beberapa negara dengan menggunakan model Bayesian VAR Approach. Melalui jalur nilai tukar dan suku bunga bekerja secara efektif di Hungaria, Republik Ceko, Rumania, dan Polandia. Namun, pengaruh dari variabel makro ekonomi di Rumania dan Polandia tidak terlalu signifikan dan menunjukkan volatilitas yang tinggi. Negara Hungaria, Republik Ceko, Rumania, dan Polandia tergabung dalam European Union sehingga dalam konteks integrasi moneter, transmisi kebijakan moneter melalui nilai tukar menjadi tidak relevan ketika menggunakan mata uang Euro. Hal ini disebabkan shock yang terjadi di Eropa akan mempengaruhi perekonomian setiap negara.

Penelitian yang sama untuk mengungkap efektivitas transmisi kebijakan moneter juga dilakukan di Arab Saudi oleh Ziaei (2012) dengan menggunakan model SVAR (Structural Vector Autoregression). Transmisi kebijakan moneter melalui nilai tukar memiliki pengaruh kuat terhadap harga, namun melalui jalur kredit lebih utama digunakan di Arab Saudi. Hal ini disebabkan sektor perbankan memiliki pengaruh kuat dalam perekonomian. Ketergantungan terhadap deposit dan cadangan bank sangat tinggi sehingga efek dari jalur kredit lebih terlihat.

Oleh karena itu penulis ingin menganalisis perkembangan kebijakan sitem nilai tukar dan variable-variabel makro seperti inflasi dan GDP di Indonesia.

\section{Landasan Teoritis}

Kebijakan Moneter

Kebijakan moneter secara umum adalah suatu usaha dalam menstabilisasi perekonomian melalui pengaturan jumlah uang beredar dan kredit agar perekonomian dapat berjalan sesuai dengan yang diinginkan. Menurut Rahardja 


\section{Jurnal Bisnis dan Kajian Strategi Manajemen}

Volume 3 Nomor 1, 2019

ISSN : 2614-2147

dan Manurung (2008:435) kebijakan moneter adalah upaya pengendalian perekonomian makro dengan cara mengatur jumlah uang beredar sehingga dapat tercapai peningkatan output dan terpeliharanya stabilitas harga.

Kebijakan moneter bertujuan untuk mencapai kestabilan ekonomi yaitu pemerataan kesempatan kerja, harga yang stabil, dan keseimbangan neraca pembayaran. Sebagai upaya menstabilkan perekonomian, Bank Sentral menggunakan instrumen kebijakan moneter. Instrumen tersebut yaitu operasi pasar terbuka (OPT), politik diskonto, cadangan wajib minimum (GWM), dan himbauan moral.

a. Operasi Pasar Terbuka (OPT)

Operasi pasar terbuka (OPT) merupakan tindakan membeli dan menjual surat berharga oleh Bank Sentral. Menurut Darmawi (2006:66) menjelaskan bahwa Bank Sentral membeli atau menjual sekuritas pemerintah dalam melaksanakan OPT. Sekuritas tersebut berupa Sertifikat Bank Indonesia (SBI) dan Surat Berharga Pasar Uang (SBPU). Pembelian sekuritas ditujukan untuk tujuan ekspansi moneter yaitu menambah jumlah uang beredar. Sebaliknya, penjualan sekuritas akan mengurangi jumlah uang beredar. Selain itu, SBI juga digunakan untuk menjaga tingkat bunga dalam pasar uang secara tidak langsung dengan mengumumkan Stop Out of Rate (SOR) sehingga diharapkan pasar dapat mengikuti SOR, yaitu tingkat bunga yang diinginkan Bank Sentral.

b. Politik Diskonto

Politik diskonto adalah tindakan pengubahan tingkat suku bunga yang harus dibayar oleh bank umum ketika bank umum meminjam dana dari Bank Sentral. Kebijakan menaikkan tingkat bunga yang dilakukan Bank Sentral akan menaikkan jumlah biaya yang harus dikeluarkan bank umum dalam meminjam dana dari Bank Sentral sehingga keinginan Bank Umum untuk meminjam juga akan berkurang, dan selanjutnya juga akan mengurangi kredit yang disalurkan oleh Bank Umum yang menyebabkan berkurang pula jumlah uang beredar. Begitu juga sebaliknya, penuruan suku bunga oleh Bank Sentral akan menurunkan biaya meminjam dana sehingga semakin banyak bank umum yang ingin meminjam. Hal ini menyebabkan jumlah uang beredar akan bertambah (Pohan, 2008:33).

c. Cadangan Wajib Minimum (Reserve Requirement Ratio)

Cadangan wajib minimum adalah suatu ketentuan dari Bank Sentral di mana Bank memiliki kewajiban untuk menyimpan sejumlah simpanan sebesar presentase tertentu. Persentasi cadangan wajib mimimum mempengaruhi daya ekspansi kredit. Kebijakan Bank Sentral dalam menurunkan cadangan minimum akan meningkatkan penyaluran kredit bank umum sehingga semakin banyak jumlah uang beredar. Sebaliknya, kebijakan Bank Sentral dalam menaikkan cadangan minimum akan menurunkan penyaluran kredit bank umum sehingga menyebabkan jumlah uang beredar berkurang (Pohan, 2008:32).

d. Himbauan Moral (Moral Persuation)

Selain tiga instrumen kebijakan moneter di atas, Bank Sentral juga dapat melakukan kebijakan himbauan moral yaitu berupa pernyatan Bank Sentral yang bersifat menghimbau melalui pemberian informasi untuk menjadi masukan bagi bank- bank umum. (Pohan, 2008:34).

Pengertian Nilai Tukar

Menurut Puspopranoto (2004:212) nilai tukar adalah harga suatu mata uang terhadap mata uang negara lainnya. Kebijakan nilai tukar terdiri dari beberapa, 


\section{Jurnal Bisnis dan Kajian Strategi Manajemen}

Volume 3 Nomor 1, 2019

ISSN : 2614-2147

yaitu fixed echange rate (sistem nilai tukar tetap), free floating exchange rate (mengambang bebas), dan managed floating exchange rate (mengambang terkendali).

Nilai tukar dapat mengalami kenaikan dan penurunan. Perubahan ini disebut dengan apresiasi dan depresiasi. Apresiasi rupiah terhadap mata uang asing adalah kenaikan rupiah dibandingkan dengan mata uang asing. Apresiasi mata uang suatu negara membuat harga barang- barang domestik menjadi lebih mahal bagi pihak luar negeri. Sementara itu, penurunan harga mata uang asing terhadap rupiah disebut dengan depresiasi. Depresiasi mata uang rupiah membuat harga barangbarang domestik menjadi lebih murah bagi pihak luar negeri.

Depresiasi rupiah berdampak buruk pada kegiatan konsumsi dan investasi. Depresiasi rupiah akan memicu kenaikan harga barang impor dan inflasi sehingga mengurangi daya beli dan konsumsi masyarakat (Rahardja dan Manurung, 2008:314).

\section{Metodologi Penelitian}

Ruang lingkup penelitian ini adalah untuk melihat dan menjelaskan perkembangan system kebijakan nilai tukar dan variable makro lainnya seperti pertumbuhan ekonomi dan inflasi. Data sekunder (annually) tahunan digunakan untuk menganalisis varaibel-variabel penelitian yaitu data kurs, growth, dan inflasi yang dibagi dalam 3 periode yaitu periode system nilai tukar tetap pada tahun 1975-1978, periode system mengambang terkendali mulai tahun 1978-1997, dan periode mengambang bebas 1997-2018. Keseluruhan data diperoleh dari laporan-laporan terbitan Bank Indonesia, Asian Development Bank, World Bank, Badan Pusat Statistik, Federal Reserve Economic Data, kantor Bank Indonesia cabang Banda Aceh, dan literatur lainnya yang berkenaan dengan topik skripsi ini.

\section{Model Analisis}

Metode analisis yang digunakan untuk menganalisis hasil penelitian ini adalah Analisis Statistik Deskriptif yang digunakan untuk analisa data dengan cara mendeskripsikan atau menggambarkan data yang diperoleh. Data tersebut harus diringkas dengan bagus dan teratur, dapat berbentuk tabel maupun grafik yang berguna sebagai dasar dalam proses pengambilan keputusan (statistik inferensi) (Gujarati, 2003: 50).

\section{Hasil dan Pembahasan}

Indonesia menerapkan sistem nilai tukar tetap dengan nilai tukar resmi Rp250/USD. Sistem nilai tukar ini diterapkan Indonesia mulai dari tahun 19641978. Selama pemberlakuan sistem ini, Bank Indonesia melakukan intervensi aktif di pasar valuta asing dengan mengontrol cadangan devisa negara. Selanjutnya, pada Tahun 1971, Indonesia melakukan kebijakan devaluasi dengan nilai tukar sebesar Rp415/USD. Kebijakan ini meningkatkan pertumbuhan ekonomi dan mengurangi tingkat inflasi, di mana pertumbuhan ekonomi Indonesia sebesar 4,97\% pada tahun 1975 meningkat menjadi 8,76\% pada Tahun 1978. Sementara itu, inflasi mengalami penurunan sebesar 19,16\% Tahun 1975 menjadi $8,76 \%$ pada Tahun 1978. Kebijakan nilai tukar tetap ini menyebabkan pemerintah aktif melakukan intervensi di pasar uang sehingga semakin mengurangi devisa negara. 
Jurnal Bisnis dan Kajian Strategi Manajemen

Volume 3 Nomor 1, 2019

ISSN : 2614-2147

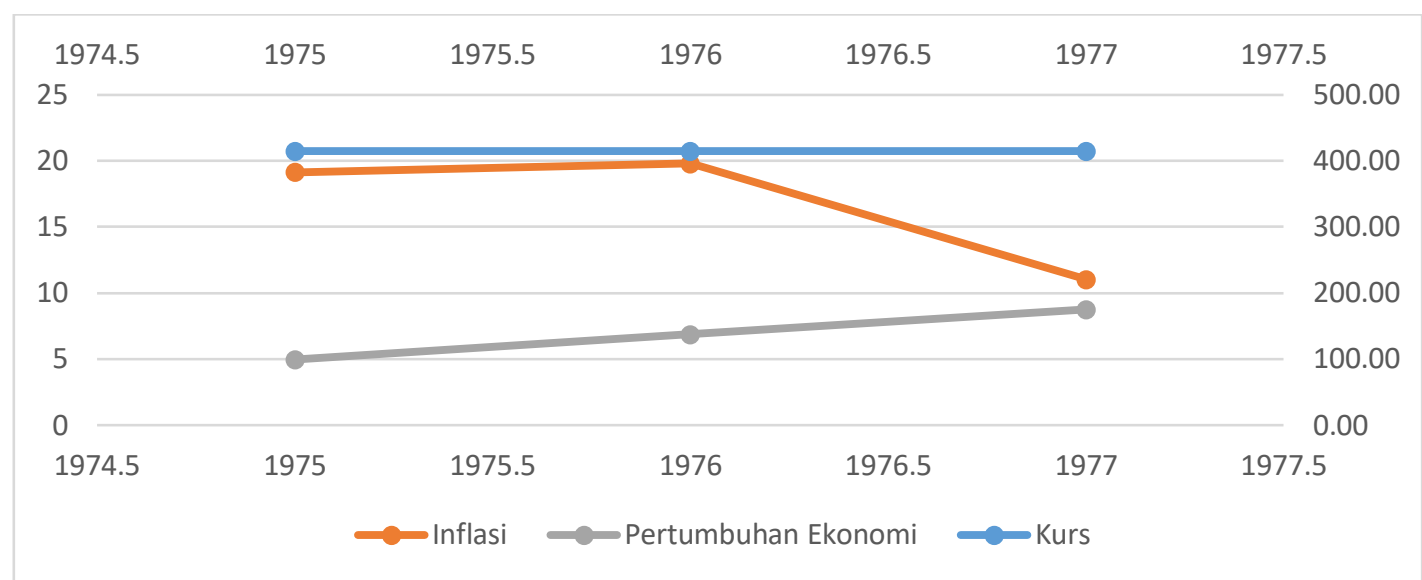

Gambar 1. Perkembangan Inflasi, Kurs, Pertumbuhan Ekonomi Tahun 19751978

Sistem nilai tukar mengambang terkendali di Indonesia ditetapkan bersamaan dengan kebijakan devaluasi rupiah. Kurs tetap dipertahankan pada tingkat Rp415/USD sejak 1971 sampai dengan pertengahan November 1998. Hal ini berpengaruh terhadap tingkat inflasi dalam negeri yang lebih tinggi dibandingkan inflasi di negara mitra dagang utama sehingga mengakibatkan melemahnya daya saing produksi dalam negeri.

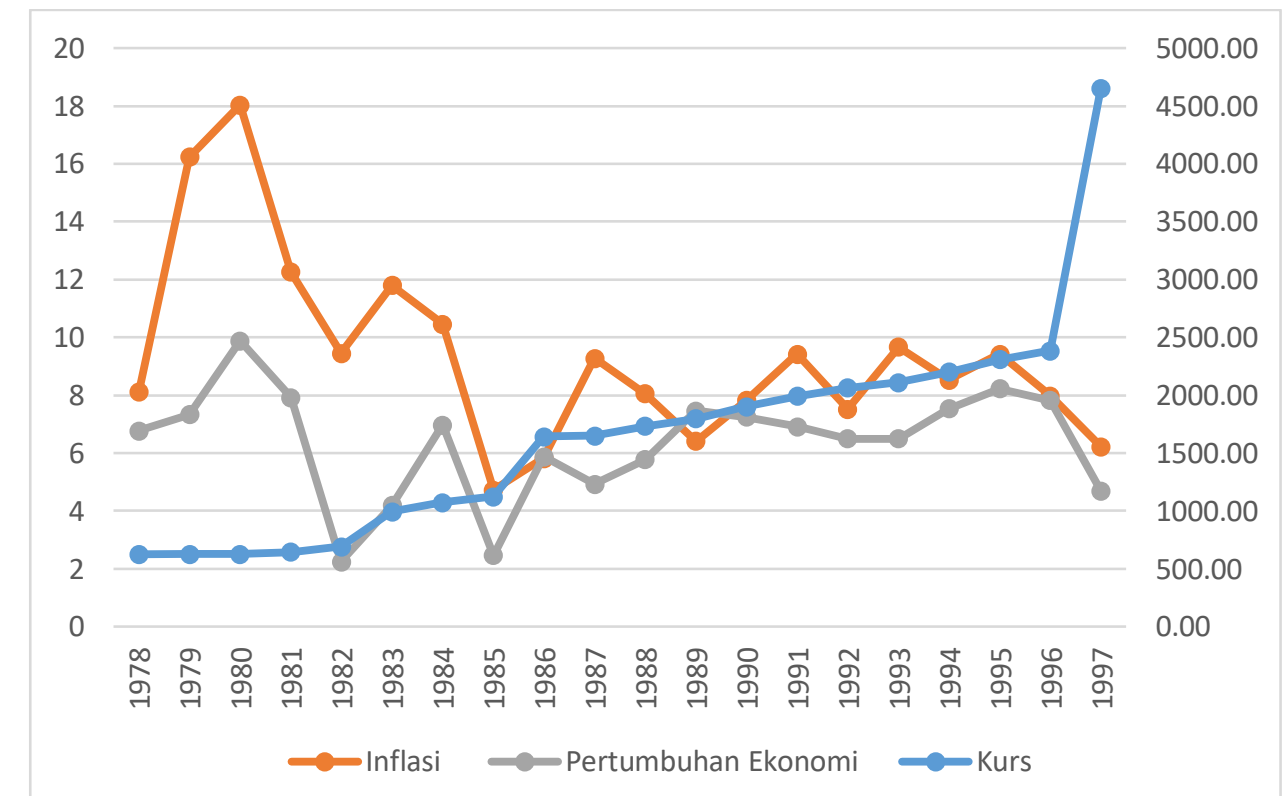

Gambar 2. Perkembangan Inflasi, Kurs, Pertumbuhan Ekonomi Tahun 19781997

Perekonomian Indonesia mengalami pasang surut dalam perkembangannya. Sebelum terjadinya krisis moneter pada tahun 1997/1998, keadaan perekonomian Indonesia cukup baik. Hal ini tercermin dari tingkat pertumbuhan yang tinggi dan perekonomian yang stabil. Puncaknya pada Tahun 1985, inflasi tercatat sebesar 4,7\%. Namun demikian, pertumbuhan ekonomi sedikit mengalami penurunan dari $6,9 \%$ menjadi $2,4 \%$ pada tahun 1984 dan 1985. Selanjutnya, pertumbuhan 


\section{Jurnal Bisnis dan Kajian Strategi Manajemen}

Volume 3 Nomor 1, 2019

ISSN : 2614-2147

ekonomi dan inflasi mulai bergerak stabil, walau maish mengalami fluktuasi. Berdasarkan data Bank Indonesia, tingkat pertumbuhan ekonomi Indonesia pada tahun 1993 hingga 1995 mengalami peningkatan dari 6,4 persen menjadi 8,2 persen. Tingkat inflasi mengalami penurunan dari 9,67 persen pada tahun 1993 menjadi 7,97 persen pada tahun 1996.

Akan tetapi pada pertengahan tahun 1997, krisis keuangan melanda dalam proses yang cepat. Krisis keuangan tahun 1997 ini merupakan awal bagi jatuhnya perekonomian Indonesia. Krisis keuangan tersebut bermula dari kebijakan pemerintah Thailand untuk mengembangkan mata uang Thailand terhadap dollar Amerika Serikat. Kebijakan devaluasi yang diterapkan pemerintah Thailand menimbulkan tekanan terhadap mata uang negara ASEAN lainnya. Ketika itu, nilai tukar mata uang di beberapa negara Asia Tenggara merosot tajam, khususnya terhadap dollar Amerika Serikat. Akibatnya, rupiah yang ketika itu relatif kuat juga mengalami penurunan yang sangat drastis. Rupiah terdepresiasi dari Rp2383/USD pada tahun 1996 mencapai Rp4650/USD pada Tahun 1997. Hal ini menyebabkan sektor ekonomi lainnya juga terkena dampak krisis tersebut. Pertumbuhan ekonomi yang diharapkan berimbas positif pada depresiasi nilai tukar dengan ekspektasi pada peningkatan ekspor namun mengalami penurunan. Pertumbuhan ekonomi tahunan (PDB riil) sebesar 4.6 persen, turun 2,2\% dari

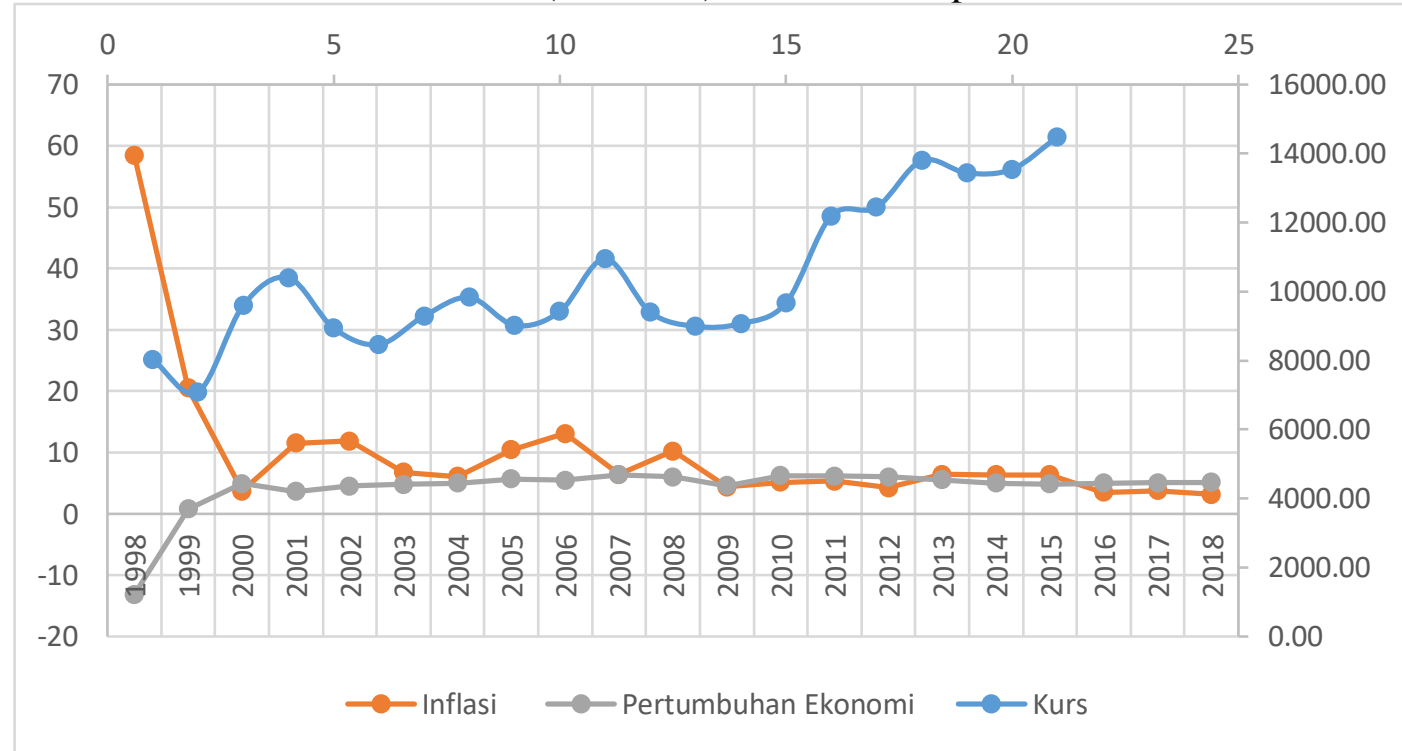

tahun 1996 yang sebesar 7,88\% dan inflasi juga tercatat sebesar 6,2\%.

Gambar 3. Perkembangan Inflasi, Kurs, Pertumbuhan Ekonomi Tahun 19781997

Krisis moneter yang melanda Indonesia menyebbakan guncangan pada perekonomian Indonesia. Oleh karena itu, pada tanggal 1 Agustus 1997 pemerintah melepas batas intervensi untuk mengamankan cadangan devisa yang terus berkurang. Indonesia menerapkan system nilai tukar bebas. Akibatnya, kurs melonjak tinggi di mana pada tahun 1998, nilai kurs Indonesia terhadap dollar Amerika mencapai Rp8.025/USD Fluktuasi kurs ini sangat berpengaruh terhadap GDP dan inflasi di mana tingkat kurs yang melonjak tajam menyebabkan pertumbuhan ekonomi Indonesia mencapai minus dan inflasi menjadi sangat tinggi. Tercatat pada tahun 1997 inflasi sebesar 6,1\% persen, dan terus meningkat 


\section{Jurnal Bisnis dan Kajian Strategi Manajemen}

Volume 3 Nomor 1, 2019

ISSN : 2614-2147

hingga mencapai 58,5\% persen pada tahun 1998. Hyper inflasi menyebabkan semua harga barang menjadi mahal sehingga daya beli masyarakat juga mengalami penurunan signifikan. Akibatnya, pada tahun tersebut, pertumbuhan ekonomi mengalami penurunan menjadi sebesar minus 13.2 persen.

Setelah krisis tahun 1997/1998, perekonomian Indonesia mulai mengalami peningkatan. Pertumbuhan ekonomi Indonesia mulai menunjukkan tingkat yang positif. Laju inflasi pun tidak mencapai hiperinflasi. Kondisi ini berhasil dipertahankan hingga pada tahun 2008. Krisis global yang melanda negara-negara besar di dunia turut berpengaruh terhadap perekonomian Indonesia. Namun, pengaruh yang ditimbulkan tidak terlalu besar.

Setelah mencatat pertumbuhan ekonomi di atas 6 persen sampai dengan tahun 2008, tahun 2009 pertumbuhan ekonomi menurun hingga mencapai 4,6 persen. Selama 2008, rupiah mencatat pelemahan hingga mencapai Rp10.950 per dollar AS.

\section{Kesimpulan dan Saran}

Kondisi kurs global sangat berpengaruh terhadap perekonomian Indonesia karena perekonomian Indonesia merupakan ekonomi terbuka kecil. Artinya, perekonomian Indonesia tidak mampu mempengaruhi perkonomian global, justru sebaliknya perekonomian Indonesia dipengaruhi oleh perekonomian global. Kebijakan nilai tukar yang diterapkan berperan penting dalam penstabilan perekonomian. Penelitian ini bertujuan untuk menganalisis mengenai perkembangan kebijakan system nilai tukar, inflasi, dan pertumbuhan ekonomi di Indonesia. Model analisis yang digunakan adalah model analisis deskriptif dengan membagi 3 periode penelitian, yaitu penerapan system nilai tukar tetap pada Tahun 1975-1978, mengambang terkendali pada tahun 1978-1997, dan periode mengambang bebas pada tahun 1997-2018. Hasil penelitian menunjukkan bahwa perkembangan system nilai tukar di Indonesia mengalami fluktuasi sepanjang tahun. Hal ini berdampak pada tingkat pertumbuhan ekonomi dan inflasi yang juga tidak stabil. Oleh karena itu, upaya menstabilkan nilai tukar rupiah perlu dilakukan oleh Bank Indonesia. Selanjutnya, untuk further study, perlu menganalisis lebih lanjut bagaimana 3 periode system nilai tukar bekerja secara efektif dalam mentransmisikan kebijakan moneter melalui jalur nilai tukar terhadap variabel makro.

\section{Daftar Pustaka}

Bernanke, B. dan Alan, Blinder. (1992). "The Federal Funds Rate and The Channel of Monetary Transmission". American Economic Review. Vol 82 No. 4.

Cevik, Serhan dan Katerina, Teksoz. (2012). "Lost in Transmission? The Effectiveness of Monetary Policy Transmission Channel in the GCC Countries. IMF Working Paper. WP 12/191.

Federal Reserve Economic Data. (2019). Publication and Statistic Data. (On Line). Tersedia : http://research.stlouisfed.org/fred2/categories/32332. Diakses : 26 September 2019.

Hung, Le Viet dan Wade, D Pfou (2008). "VAR Analysis of the Monetary 
Transmission Mechanism in Vietnam”. Working Paper 081, Vietnam Development Forum.

Pohan, Aulia. (2008). Kerangka Kebijakan Moneter dan Implementasinya di Indonesia. PT Raja Grafindo Persada, Jakarta.

(2008). Potret Kebijakan Moneter Indonesia. PT Raja Grafindo Persada, Jakarta.

Puspopranoto, Sawaldjo. (2004). Keuangan dan Perbankan dan Pasar Keuangan: Konsep, Teori, dan Realita. Pustaka LP3ES Indonesia, Jakarta.

Rahardja, Prathama dan Mandala, Manurung. (2008). Pengantar Ilmu Ekonomi, Edisi Ketiga. Penerbit Fakultas Ekonomi Universitas Indonesia, Jakarta.

Rosoiu, Andreea and Iulia, Rosoiu. (2013). "Monetary Policy Transmission Mechanism In Emerging Countries". Cross-Cultural Management Journal. Volume 15, Issue 2 (28). Pages 129-141.

Sulasmiyati, Sri. (2008). "Sistem Nilai Tukar Mata Uang dan Penerapannya di Indonesia. ”Jurnal Administrasi Indonesia. Vol 2, No. 1 : 243-251

Undang-undang Republik Indonesia Nomor 23 Tahun 1999 Tentang Bank Indonesia.

Warjiyo, Perry. (2004). Mekanisme Transmisi Kebijakan Moneter Di Indonesia. Pusat Pendidikan Dan Studi Kebanksentralan (PPSK) Bank Indonesia, Jakarta.

Ziaei, Sayyed Mahdi. (2012). "Transmission Mechanisms of Monetary Policy in Saudi Arabia: Evidence From SVAR Analysis". Journal of Modern Accounting and Auditing. ISSN 1548-6583 July 2012, Vol. 8, No. 7, 990101. 